\title{
Alteration in the activities of antioxidant enzymes and lipid peroxidation in mice transplanted with Dalton's lymphoma ascites tumor by Helicia nilagirica Bedd
}

\begin{abstract}
The present study was performed to obtain an insight into the biochemical profile of Dalton's lymphoma ascites tumour bearing Swiss albino mice treated with aqueous extract of Helicia nilagirica. The mice bearing Dalton's lymphoma ascites tumor was injected with $175 \mathrm{mg} / \mathrm{kg}$ body weight of aqueous extract of $H$. nilagirica for nine consecutive days. Thereafter, the tumour cells were aspirated at 2, 4, 6, 8, 12 and $24 \mathrm{~h}$ post drug treatment for the estimation of glutathione, glutathione-s-transferase, catalase, superoxide dismutase, and lipid peroxidation. The administration of tumorized mice with $H$. nilagirica aqueous extract caused a significant depletion in the glutathione contents and activities of glutathione-stransferase, catalase, superoxide dismutase in a time dependent manner up to $24 \mathrm{~h}$ post assay time, when compared to sterile physiological saline treated group. In contrast, treatment of tumorized mice with $H$. nilagirica aqueous extract resulted in a time dependent rise in the lipid peroxidation when compared to sterile physiological saline treated group. Our study demonstrates that the cytotoxic effect of $H$. nilagirica aqueous extract on Dalton's lymphoma ascites tumour cells may be due to increased lipid peroxidation and reduction in the glutathione contents, activities of glutathione-s-transferase, catalase, and superoxide dismutase.
\end{abstract}

Keywords: mice, Helicia nilagirica, dalton's lymphoma, glutathione, antioxidant enzymes, lipid peroxidation
Volume 6 Issue 4 - 2019

\author{
Ganesh Chandra Jagetia, Jennifer Zoremsiami \\ Department of Zoology, Mizoram University, India
}

Correspondence: Ganesh Chandra Jagetia, 10, Maharana Pratap Colony, Sector-13, Hiran Magri, Udaipur-3 I 3002, India, Email gc.jagetia@gmail.com

Received: May 24, 2019 | Published: August 22, 2019

\begin{abstract}
Abbreviations: DETAPAC, diethylenetriaminopentaacetic acid; CDNB, 1-chloro-2,4-dinitrobenzene; EDTA, ethylenediaminetertaacetic acid; DTNB, 5,5-dithiobis(2-nitrobenzoic acid); NBT, nitrobluetetrazolium; PMS, phenazine methosulphate; TBA, 2-thiobarbituric acid; SDS, sodium dodecyl sulphate; NADH, nicotinamide adenine dinucleotide; NADPH, nicotinamide adenine dinucleotide phosphate; TNB, 5-thio-(2-nitrobenzoic acid)]
\end{abstract}

\section{Introduction}

The plants and various microbes synthesize various secondary metabolites having complex chemical structure. Many of these secondary metabolites have formed the basis of numerous pharmacological agents. ${ }^{1,2}$ The screening of plants has provided an avenue for new drug discovery and many of the modern drugs have been isolated from the natural products. ${ }^{3-5}$ The modern chemotherapy drugs have been very useful in cancer treatment however, their constant use leads to acquired drug resistance. ${ }^{6,7}$ The complementary and alternative medicinal systems as treatment modalities is very old and they have been followed in various countries. ${ }^{8}$ The cancer patients also use these systems for healthcare in different countries, which emphasizes the importance of these system. ${ }^{9-13}$ This has given an impetus to screen natural products for new drug discovery.

Helicia nilagirica Bedd. or Pasaltakaza in Mizo language (Family: Proteaceae) grows in lowlands to montane rain forests, up to an altitude of 1000 to 2,000 meters. It is also found along the streams, hilltops and ridges. ${ }^{14} \mathrm{H}$. nilagirica is traditionally used by tribals of Mizoram, India to treat indigestion, stomach ailments, peptic ulcers, gynaecological disorders, mouth ulcers and urinary tract infections. H. nilagirica is also used in the treatment of scabies and some skin disorders. ${ }^{15,16} H$. nilagirica fruits are used in Sikkim to provide relief to cure cough and cold. ${ }^{15,16}$ There has been a recent report regarding the anti-inflammatory activity of $H$. nilagirica. ${ }^{17}$ The $H$. nilagirca aqueous extract has been reported to exert antineoplastic activity in vitro and in Dalton's lymphoma ascites cells in tumorized mice ${ }^{15,16}$ However, the systematic scientific evaluation of antioxidant enzymes and lipid peroxidation of $H$. nilagirica has not been studied. Therefore, the present study was performed to obtain an insight into the biochemical profile of Dalton's lymphoma ascites tumour in Swiss albino mice treated with aqueous extract of Helicia nilagirica.

\section{Materials and methods}

\section{Chemicals}

Glutathione (reduced), diethylenetriaminopentaacetic acid (DETAPAC), 1-chloro-2,4-dinitrobenzene (CDNB), ethylenediaminetertaacetic acid (EDTA), 5,5-dithiobis(2nitrobenzoic acid) (DTNB), nitrobluetetrazolium (NBT), phenazine methosulphate (PMS), sodium azide, 2-thiobarbituric acid (TBA), sodium dodecyl sulphate (SDS), nicotinamide adenine dinucleotide $(\mathrm{NADH})$, nicotinamide adenine dinucleotide phosphate (NADPH), 
tetraethoxypropane, and 5-thio-(2-nitrobenzoic acid)] (TNB) were purchased from Sigma Chemicals Co. St. Louis, USA. Other routine chemicals were procured from Merck India, Mumbai. Doxorubicin hydrochloride was procured from Getwell Pharmaceuticals, Gurgaon, India.

\section{Animal care handling}

The animal care and handling were carried out according to the guidelines of the INSA (Indian National Science Academy, New Delhi, India) and the World Health Organization, Geneva, Switzerland. Swiss albino mice were purchased from Pasteur Institute, Shillong, India and were bred before use in a controlled environment of temperature $\left(24-25^{\circ} \mathrm{C}\right), 50 \%$ humidity and $12 \mathrm{~h}$ each of light and dark cycle. Usually 5-6 animals were housed in a sterile polypropylene cage containing paddy husk (procured locally) as bedding material. Six to eight weeks old female Swiss albino mice weighing 20-30g were used for the experimentation. The animals were maintained on commercially available food pellets and water ad libitum. All animal experiments were carried out according to NIH and Indian National Science Academy, New Delhi, India guidelines. The Institutional Animal Ethics Committee of Mizoram University, approved the entire study vide letter no. MZUIAEC141513, Aizawl, India.

\section{Collection and preparation of the extract}

The non-infected stem bark of Helicia nilagirica Bedd. (Family: Protaeceae) or Pasaltakaza was collected from Sialsuk, Aizawl District of Mizoram, India during the dry season and it was identified and authenticated by Botanical Survey of India, Shillong. The dried and cleaned stem bark of $H$. nilagirica was chopped into small pieces, and shade dried at room temperature in the dark and ground to powder at room temperature using an electrical grinder. The dried stem bark powder was weighed and $100 \mathrm{~g}$ of bark powder was sequentially extracted in petroleum ether, chloroform, ethanol and water in a Soxhlet apparatus..$^{15,16}$ All the extracts were collected and dried by evaporating their liquid contents under reduced pressure. The aqueous extract was stored at $-80^{\circ} \mathrm{C}$ until further use and will be called as HNA hereafter.

\section{Preparation of drug and mode of administration}

The HNA was dissolved in sterile physiological saline (SPS), which was used for the present study. The animals were administered intraperitoneally with aqueous extract according to their body weight for nine consecutive days 1 day after tumor transplantation. ${ }^{16}$

\section{Tumor model}

Dalton's lymphoma ascites (DLA) tumour was procured from the Department of Zoology, North- Eastern Hills University, Shillong and was maintained in the 10-12 weeks old female mice by serial intraperitoneal transplantation of $1 \times 10^{6}$ viable tumour cells per animal (in $0.25 \mathrm{ml}$ PBS, $\mathrm{pH} 7.4$ ) under aseptic condition. The tumorized mice were used for experiments one day after inoculation of DLA cells.

\section{Experimental}

The effect of HNA on the activities of glutathione-s-transferase (GST), catalase (CAT), superoxide dismutase (SOD), glutathione (GSH) and lipid peroxidation (LOO) were assessed in the Dalton's lymphoma tumor bearing mice by dividing them into the following groups:
SPS groups: This group of tumorized mice received $0.01 \mathrm{ml} / \mathrm{kg}$ body weight of SPS and served as negative control.

DOX groups: This group of tumorized animals was injected with $0.5 \mathrm{mg} / \mathrm{kg}$ body weight of doxorubicin, a standard anticancer drug and served as positive control.

HNA groups: The tumorized animals of this group were injected with $175 \mathrm{mg} / \mathrm{kg}$ body weight of the aqueous extract of Helicia nilagirica.$^{16}$

\section{Biochemical assays}

The tumourized animals were euthanized after nine days of drug/s treatment at an interval of 2, 4, 6, 8, 12 and $24 \mathrm{~h}$ post HNA treatment. Both the treated and untreated Dalton's lymphoma cells were aspirated under sterile conditions, washed with ammonium chloride and SPS and pelleted. The cell pellets were weighed and 5\% homogenate was prepared in cold, sterile PBS (pH 7.4), which was used for the estimation GSH, GST, CAT, SOD and LOO. ${ }^{17}$

\section{Total proteins}

The estimation of total proteins was carried out as described earlier. $^{18}$

\section{Estimation of glutathione}

Glutathione concentration was estimated as described earlier. ${ }^{19}$ Glutathione was measured by its reaction with DTNB to give a compound that absorbs light at $412 \mathrm{~nm}$. In brief, to $1.8 \mathrm{ml}$ of $0.2 \mathrm{M}$ $\mathrm{Na}_{2} \mathrm{HPO}_{4}, 40 \mu \mathrm{l}$ of $10 \mathrm{mM}$ DTNB and $160 \mu$ l of cell homogenate were mixed and allowed to stand for 2 minutes. The absorbance was read against the blank at $412 \mathrm{~nm}$ in a UV-VIS spectrophotometer (SW 3.5.1.0. Biospectrometer, Eppendorf India Ltd., Chennai).

\section{Estimation of glutathione-S-transferase}

Glutathione-s-transferase was determined using standard protocol. ${ }^{20}$ Usually, $0.5 \mathrm{ml}$ of $0.1 \mathrm{M}$ phosphate buffer $(\mathrm{pH} 6.5), 0.1 \mathrm{ml}$ of $20 \mathrm{mM} \mathrm{CDNB}$, and $8.8 \mathrm{ml}$ distilled water were incubated at $37^{\circ} \mathrm{C}$ for $10 \mathrm{~min}$ followed by the addition of $0.5 \mathrm{ml}$ of $20 \mathrm{mM}$ GSH and $0.1 \mathrm{ml}$ of cell homogenate. The absorbance was read at $340 \mathrm{~nm}$ with a UV-VIS spectrophotometer at 1 min intervals for 6 minutes. The GST activity was estimated using the following formula:

GST activity $=$ Absorbance of sample - Absorbance of blank $\times$ 1000/9.6 × Sample Volume

\section{Catalase assay}

Catalase was assayed according to the technique described by Aebi. ${ }^{21}$ In a $3 \mathrm{ml}$ cuvette, $20 \mu \mathrm{l}$ of cell homogenates was mixed with $1.98 \mathrm{ml}$ of $50 \mathrm{mM}$ phosphate buffer $(\mathrm{pH} 7.0)$. The reaction (maintained at $20^{\circ} \mathrm{C}$ ) was started by the addition of $1 \mathrm{ml}$ of $30 \mathrm{mM} \mathrm{H}_{2} \mathrm{O}_{2}$. The decrease in absorbance was monitored at $240 \mathrm{~nm}$ for 60 seconds.

\section{Superoxide dismutase assay}

The activity of SOD was estimated by the protocol described by Fried et al..$^{22}$ Briefly, $100 \mu 1$ of cell homogenate, $100 \mu 1$ of $186 \mu \mathrm{M}$ PMS, $300 \mu 1$ of $3 \mathrm{mM}$ NBT, $200 \mu 1$ of $780 \mu \mathrm{M}$ NADH were mixed and incubated for 90 seconds at $30^{\circ} \mathrm{C}$. The reaction was terminated by adding $1000 \mu \mathrm{l}$ of acetic acid followed by the addition of $4 \mathrm{ml}$ n-butanol. The absorbance was recorded at $560 \mathrm{~nm}$ using UV/ VIS spectrophotometer. The percent inhibition was calculated by 
measuring the absorbance of blank without SOD enzyme. The SOD activity was calculated using the formula:- Blank-Sample/Blank X 100 .

\section{Lipid peroxidation assay}

Malondialdehyde (MDA) formed from the breakdown of polyunsaturated fatty acids, serve as a convenient index for determining the extent of peroxidation reaction of lipids. MDA has been identified as the product of LOO that reacts with TBA to give a red species absorbing at $535 \mathrm{~nm}$. LOO assay was carried out following the method of Buege \& Aust $^{23}$ One $\mathrm{ml}$ of tissue homogenate was added to $2 \mathrm{ml}$ of TCA-TBA-HCl reagent and mixed thoroughly. The mixture was heated in a boiling water bath for 15 minutes, cooled immediately at room temperature and centrifuged at $1000 \mathrm{rpm}$ for $10 \mathrm{~min}$. The supernatant was collected and its absorbance was read at $535 \mathrm{~nm}$ against blank in a UV-VIS spectrophotometer. The blank contained all the reagents minus the cell homogenate substituted with distilled water.

Table I Alteration in the glutathione contents of mice bearing Dalton's lymphoma treated with I75mg/kg body weight aqueous Helicia nilagirica extract (HNA) or $0.5 \mathrm{mg} / \mathrm{kg}$ body weight doxorubicin (DOX).

\begin{tabular}{llll}
\hline \multirow{2}{*}{ Post treatment time $(\mathbf{h})$} & \multicolumn{3}{l}{ Glutathione $(\boldsymbol{\mu m} / \mathrm{mg}$ protein) } \\
\cline { 2 - 4 } & \multicolumn{2}{l}{ Mean \pm SEM } & DOX \\
\cline { 2 - 4 } & SPS & HNA & $2.39 \pm 0.0$ * $^{*}$ \\
\hline 2 & $5.09 \pm 0.15$ & $2.92 \pm 0.29^{*}$ & $2.36 \pm 0.18^{*}$ \\
4 & $5.18 \pm 0.17$ & $3.86 \pm 0.37^{*}$ & $2.74 \pm 0.14^{*}$ \\
6 & $5.25 \pm 0.14$ & $3.67 \pm 0.08^{*}$ & $2.23 \pm 0.09^{*}$ \\
12 & $5.09 \pm 0.07$ & $2.41 \pm 0.07^{*}$ & $2.34 \pm 0.05^{*}$ \\
24 & $5.66 \pm 0.07$ & $2.94 \pm 0.08^{*}$ & $2.58 \pm 0.06^{*}$ \\
\hline
\end{tabular}

$*_{\mathrm{p}}<0.05$ when treatments are compared with concurrent SPS (sterile physiological saline) control group

No symbol= Non-significant. $\mathrm{N}=10$

Table 2 Alteration in the glutathione-S-transferase (GST) activity of Mice bearing Dalton's lymphoma treated with I75mg/kg body weight aqueous Helicia nilagirica extract (HNA) or $0.5 \mathrm{mg} / \mathrm{kg}$ body weight doxorubicin (DOX).

\begin{tabular}{llll}
\hline \multirow{2}{*}{ Post treatment time $(h)$} & \multicolumn{2}{l}{ Glutathione-S-transferase activity (U/mg protein) } \\
\cline { 2 - 4 } & \multicolumn{2}{l}{ Mean \pm SEM } & DOX \\
\cline { 2 - 4 } & SPS & HNA & $0.04 I \pm 01$ I \\
\hline 2 & $0.054 \pm 0.001$ & $0.041 \pm 005$ & $0.033 \pm 007^{*}$ \\
4 & $0.076 \pm 0.008$ & $0.032 \pm 004^{* *}$ & $0.033 \pm 003^{*}$ \\
6 & $0.070 \pm 0.012$ & $0.035 \pm 003^{* *}$ & $0.023 \pm 002^{*}$ \\
12 & $0.058 \pm 0.004$ & $0.033 \pm 007^{* *}$ & $0.035 \pm 001 *$ \\
24 & $0.072 \pm 0.007$ & $0.043 \pm 003^{* *}$ & $0.027 \pm 002^{*}$ \\
\hline
\end{tabular}

${ }^{*} \mathrm{p}<0.05$ when treatments are compared with concurrent SPS (Sterile Physiological Saline) control group

* $\mathrm{p}<0.000$ I When comparisons are made between different times by One-way ANOVA with Tukey's post-hoc test.

No symbol= Non-significant. $\mathrm{N}=10$.

Citation: Jagetia GC, Zoremsiami J.Alteration in the activities of antioxidant enzymes and lipid peroxidation in mice transplanted with Dalton's lymphoma ascites tumor by Helicia nilagirica Bedd. MOJ Anat \& Physiol. 2019;6(4): I35- |43. DOI: I0.15406/mojap.2019.06.0026 I 
Table 3 Alteration in the catalase activity of mice bearing Dalton's lymphoma treated with $175 \mathrm{mg} / \mathrm{kg}$ body weight aqueous Helicia nilagirica extract (HNA) or $0.5 \mathrm{mg} / \mathrm{kg}$ body weight doxorubicin (DOX).

\begin{tabular}{llll}
\hline Post treatment time $(h)$ & \multicolumn{2}{l}{ Catalase activity $($ U/mg protein) } \\
\cline { 2 - 4 } & \multicolumn{2}{l}{ Mean \pm SEM } & DOX \\
\cline { 2 - 4 } & SPS & $19.57 \pm 1.12^{*}$ & $15.49 \pm 0.31^{*}$ \\
\hline 2 & $24.49 \pm 0.49$ & $19.05 \pm 0.37^{*}$ & $17.09 \pm 0.28^{*}$ \\
4 & $22.61 \pm 1.26$ & $16.47 \pm 0.37^{*}$ & $13.73 \pm 1.72^{*}$ \\
6 & $23.47 \pm 0.40$ & $14.32 \pm 1.65^{* \alpha}$ & $13.81 \pm 0.84^{*}$ \\
8 & $23.51 \pm 0.63$ & $14.49 \pm 0.40^{* \alpha}$ & $11.18 \pm 1.28^{*}$ \\
12 & $23.99 \pm 0.56$ & $11.74 \pm 0.51^{* \alpha}$ & $10.55 \pm 0.39^{*}$ \\
24 & $22.92 \pm 1.80$ & & \\
\hline
\end{tabular}

${ }^{*} \mathrm{p}<0.05$ When treatments are compared with concurrent SPS (Sterile Physiological Saline) control group ${ }^{a} \mathrm{p}<0.0$ I When comparisons are made between different times by One-way ANOVA with Tukey's post-hoc test. No symbol= Non-significant. $\mathrm{N}=10$.

Table 4 Alteration in the superoxide dismutase (SOD) activity in mice bearing Dalton's lymphoma treated with $175 \mathrm{mg} / \mathrm{kg}$ body weight aqueous Helicia nilagirica extract (HNA) or $0.5 \mathrm{mg} / \mathrm{kg}$ body weight doxorubicin (DOX).

\begin{tabular}{|c|c|c|c|}
\hline \multirow[t]{3}{*}{ Post treatment time (h) } & \multicolumn{3}{|c|}{ Superoxide dismutase (SOD) activity (U/mg protein) } \\
\hline & \multicolumn{3}{|c|}{ Mean \pm SEM } \\
\hline & SPS & HNA & DOX \\
\hline 2 & $1.91 \pm 0.006$ & $0.87 \pm 0.07^{*}$ & $0.76 \pm 0.05^{*}$ \\
\hline 4 & $1.93 \pm 0.002$ & $1.35 \pm 0.03^{* *}$ & $0.88 \pm 0.04 *$ \\
\hline 6 & $1.94 \pm 0.001$ & $1.50 \pm 0.01 * *$ & $1.18 \pm 0.14 *$ \\
\hline 8 & $1.92 \pm 0.009$ & $1.08 \pm 0.02 * *$ & $0.79 \pm 0.08^{*}$ \\
\hline 12 & $1.93 \pm 0.002$ & $1.19 \pm 0.04 * *$ & $1.01 \pm 0.05^{*}$ \\
\hline 24 & $1.94 \pm 0.003$ & $1.11 \pm 0.06 * *$ & $0.58 \pm 0.06 *$ \\
\hline
\end{tabular}

$*_{\mathrm{p}}<0.05$ when treatments are compared with concurrent SPS (Sterile Physiological Saline) control group.

" $\mathrm{p}<0.000$ I When comparisons are made between different times by One-way ANOVA with Tukey's post-hoc test. No symbol= Non-significant. $\mathrm{N}=10$

Table 5 Alterations in the lipid peroxidation level in mice bearing Dalton's lymphoma treated with 175 mg/kg body weight aqueous Helicia nilagirica extract (HNA) or $0.5 \mathrm{mg} / \mathrm{kg}$ body weight doxorubicin (DOX).

\begin{tabular}{llll}
\hline Post treatment time $(\mathbf{h})$ & \multicolumn{4}{l}{ Lipid peroxidation (MDA) Mean \pm SEM, (nmol /mg protein) } \\
\cline { 2 - 4 } & \multicolumn{1}{l}{ SPS } & HNA & DOX \\
\hline 2 & $3.87 \pm 0.05$ & $4.16 \pm 0.0 I^{*}$ & $5.06 \pm 0.02 *$ \\
4 & $3.55 \pm 0.02$ & $4.23 \pm 0.03^{* *}$ & $5.53 \pm 0.02 *$ \\
6 & $3.69 \pm 0.08$ & $4.45 \pm 0.06^{* *}$ & $5.82 \pm 0.14^{*}$ \\
8 & $3.99 \pm 0.03$ & $4.65 \pm 0.02 * *$ & $6.47 \pm 0.62 *$ \\
12 & $3.91 \pm 0.06$ & $4.97 \pm 0.01 * *$ & $6.51 \pm 0.10^{*}$ \\
24 & $3.83 \pm 0.06$ & $5.22 \pm 0.02 * *$ & $7.03 \pm 0.02 *$ \\
\hline
\end{tabular}

$*_{p}<0.05$ when treatments are compared with concurrent SPS (Sterile Physiological Saline) control group

${ }^{\alpha} \mathrm{p}<0.0 \mathrm{I}$ and * $\mathrm{p}<0.000 \mathrm{I}$ When comparisons are made between different times by One-way ANOVA with Tukey's post-hoc test.

No symbol= Non-significant. $\mathrm{N}=10$ 


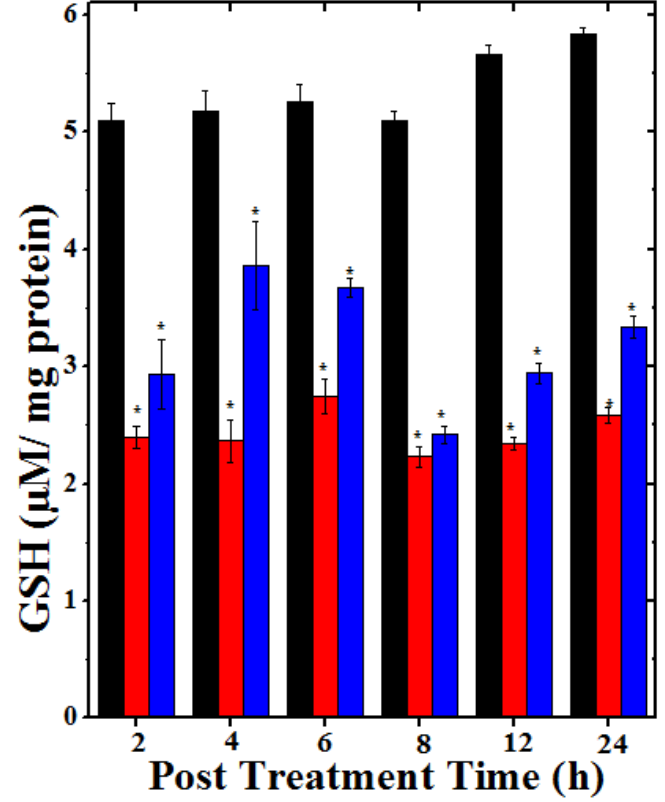

Figure I Alteration in the glutathione content of mice bearing Dalton's lymphoma ascites tumor treated with $175 \mathrm{mg} / \mathrm{kg}$ body weight of Helicia nilagirica extract and $0.5 \mathrm{mg} / \mathrm{kg}$ body weight doxorubicin. Black bars: Sterile physiological saline; Red bars: Doxorubicin and Blue bars: Helicia nilagirica extract. The results are expressed as the Mean $\pm \mathrm{SEM}, \mathrm{N}=10$. ${ }^{*} p<0.05$ when treatments are compared with concurrent SPS (Sterile Physiological Saline) control group.

No symbol= Non-significant.

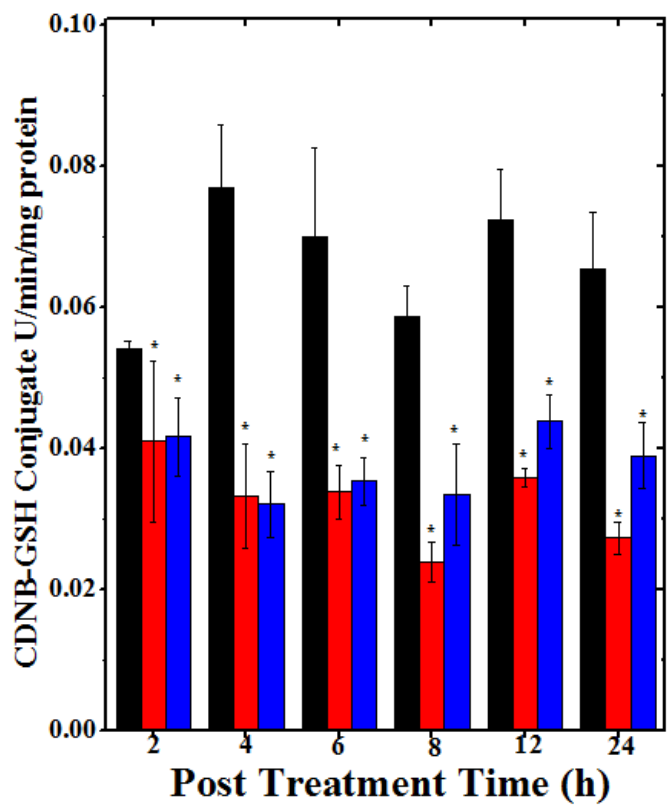

Figure 2 Alteration in the glutathione $-s$ - transferase content of mice bearing Dalton's lymphoma ascites tumor treated with $175 \mathrm{mg} / \mathrm{kg}$ body weight of Helicia nilagirica extract and $0.5 \mathrm{mg} / \mathrm{kg}$ body weight doxorubicin. Black bars: Sterile physiological saline; Red bars: Doxorubicin and Blue bars: Helicia nilagirica extract. The results expressed as the Mean \pm SEM, N=10. $*_{p}<0.05$ when treatments are compared with concurrent SPS (Sterile Physiological Saline) control group. No symbol= Non-significant.

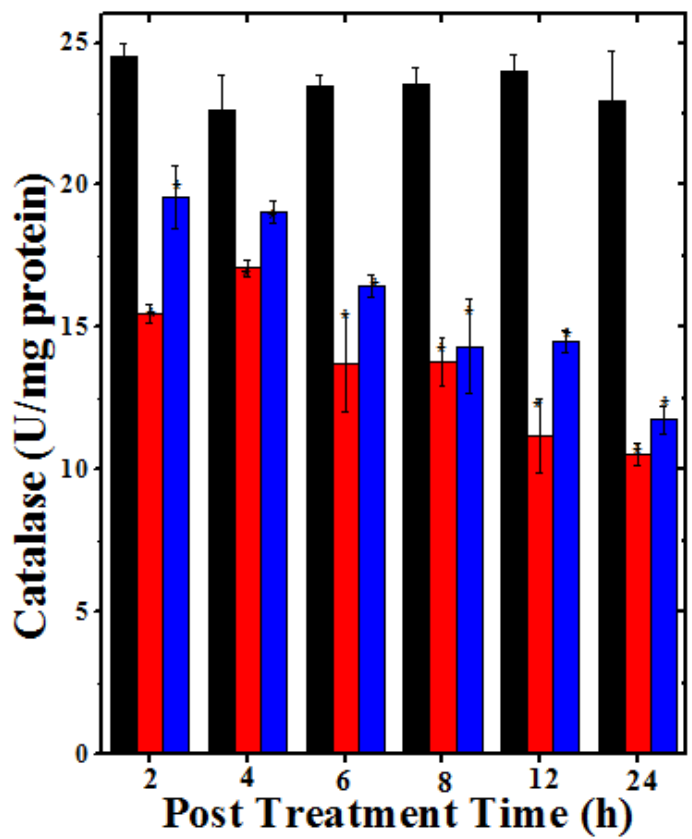

Figure 3 Alteration in the catalase activity of mice bearing Dalton's lymphoma ascites treated with $175 \mathrm{mg} / \mathrm{kg}$. body weight of Helicia nilagirica extract and $0.5 \mathrm{mg} / \mathrm{kg}$ body weight doxorubicin. Black bars: Sterile physiological saline; Red bars: Doxorubicin and Blue bars: Helicia nilagirica extract. The results expressed as the Mean \pm SEM, N=10. ${ }^{*} p<0.05$ when treatments are compared with concurrent SPS (Sterile Physiological Saline) control group. No symbol= Non-significant.

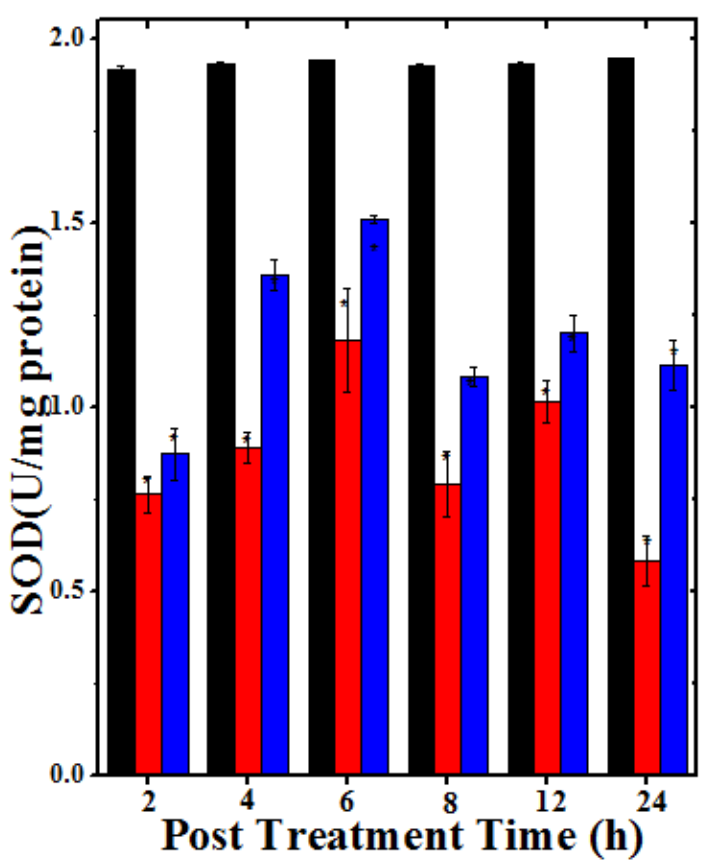

Figure 4 Alteration in the superoxide dismutase activity of mice bearing Dalton's lymphoma ascites tumor treated with $175 \mathrm{mg} / \mathrm{kg}$. body weight of Helicia nilagirica extract and $0.5 \mathrm{mg} / \mathrm{kg}$ body weight doxorubicin. Black bars: Sterile physiological saline; Red bars: Doxorubicin and Blue bars: Helicia nilagirica extract. The results expressed as the Mean \pm SEM, N=10. $* p<0.05$ when treatments are compared with concurrent SPS (Sterile Physiological Saline) control group. No symbol= Non-significant. 


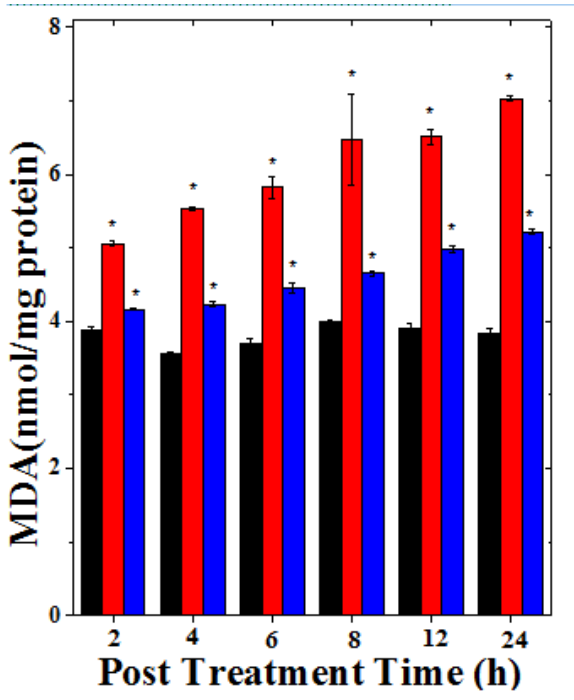

Figure 5 Alterations in the lipid peroxidation level in the Dalton's lymphoma ascites bearing mice treated with $175 \mathrm{mg} / \mathrm{kg}$. Body weight of Helicia nilagirica extract and $0.5 \mathrm{mg} / \mathrm{kg}$ body weight Doxorubicin. Black bars: Sterile physiological saline; Red bars: Doxorubicin and Blue bars: Helicia nilagirica extract. The results present the Mean $\pm \mathrm{SEM}, \mathrm{N}=10$.

$*_{p}<0.05$ when treatments are compared with concurrent SPS (Sterile Physiological Saline) control group.

No symbol= Non-significant.

\section{Glutathione}

The DLA mice showed $5.09 \pm 0.15 \mu \mathrm{m} / \mathrm{mg}$ protein as baseline glutathione concentration and it did not alter significantly with different assay times (Table 1). The tumour bearing mice treated with $175 \mathrm{mg} /$ $\mathrm{kg}$ body weight of HNA and $0.5 \mathrm{mg} / \mathrm{kg}$ body weight of doxorubicin showed a decrease in glutathione contents in a time dependent manner up to $24 \mathrm{~h}$ post drug treatment (Figure 1). The maximum decline was found at $8 \mathrm{~h}$ posttreatment for both HNA and DOX groups where the decreases were 2 folds for HNA and 2.8 folds for DOX group, respectively. Thereafter, the GSH concentration stated rising however, it did not reach to negative control level even at $24 \mathrm{~h}$ post treatment (Figure 1). The alleviation of glutathione contents in all the treatment groups was significant $(\mathrm{p}<0.05)$ when compared with the concurrent control group (Table 1).

\section{Glutathione-S-transferase (GST)}

The spontaneous activity of GST in DLA cells was estimated as $0.054 \pm 0.001 \mathrm{U} / \mathrm{mg}$ protein and it did not show any significant change with increase in assay time (Table 2). The administration of HNA or DOX resulted in a time dependent decline in the GST activity (Figure 2 ) and a maximum decline in the GST activity was recorded at $4 \mathrm{~h}$ post drug treatment for HNA ( 2.4 fold) and $8 \mathrm{~h}$ for DOX (2.5 fold) (Table 2). Thereafter a marginal elevation in the GST activity was observed however, it did not reach to negative control level (Table $2)$. The decline in the GST activity was significant $(\mathrm{p}<0.05)$ at all the post treatment times except $2 \mathrm{~h}$ when compared with the concurrent negative control group (Table 2).

\section{Catalase (CAT) activity}

The CAT activity in DLA cells recorded in SPS group has been $24.49 \pm 0.49 \mathrm{U} / \mathrm{mg}$ protein at $2 \mathrm{~h}$ post treatment, which did not change significantly with time up to $24 \mathrm{~h}$ (Table 3 ). Treatment of tumorized mice with HNA or DOX resulted in a significant decline in the CAT activity at each assay time when compared to SPS group (Table 3). The CAT activity in the HNA and DOX treated groups declined with the increasing assay time and the greatest reduction was found at $24 \mathrm{~h}$ post drug treatment (Figure 3). However, a significant decline was observed only at $8-24 \mathrm{~h}$ post assay times (Table 3 ). This decrease was 1.95 folds for HNA and 2.2 folds for DOX, respectively (Table 3 ). All the treatment groups showed a significant $(\mathrm{p}<0.05)$ decline when compared with the negative concurrent control group (Table 3).

\section{Superoxide dismutase (SOD) activity}

The spontaneous activity of SOD was measured as $1.91 \pm 0.006$ $\mathrm{U} / \mathrm{mg}$ protein at $2 \mathrm{~h}$ post-treatment, which did not alter significantly with assay time in SPS group (Table 4). The administration of HNA $(175 \mathrm{mg} / \mathrm{kg}$ body weight $)$ and DOX $(0.5 \mathrm{mg} / \mathrm{kg}$ body weight $)$ resulted in a significant $(\mathrm{p}<0.05)$ decline in SOD activity when compared to SPS group (Table 4). The greatest reduction in SOD activity was observed at $2 \mathrm{~h}$ for HNA (2.2 fold) and (2.5 fold) for DOX, respectively (Table 4). Treatment of tumorized mice with HNA led to a significant decline $(p<0.0001)$ in the GST activity with time except for $12 \mathrm{~h}$ where it was highest (Figure 4). The SOD activity increased thereafter and a second phase of decline (Figure 4) was noticed at $8 \mathrm{~h}$ post treatment in both HNA and DOX groups where it was 1.8 and 2.4 folds, respectively (Table 4).

\section{Lipid peroxidation}

The SPS group of tumorized mice showed MDA value of $3.87 \pm 0.05$, which did not show significant alteration with increasing assay time (Table 5). Treatment of DLA mice with HNA or DOX resulted in a continuous rise in the lipid peroxidation up to $24 \mathrm{~h}$ post treatment (Figure 5). This increase in LOO was significantly $(\mathrm{p}<0.05)$ higher in comparison to SPS group (Table 5). The increase in lipid peroxidation was 1.36 folds for HNA and 1.83 folds for DOX at $24 \mathrm{~h}$ posttreatment time (Table 5). The LOO increased significantly with assay time in HNA group when comparisons are made among different times (Table 5).

\section{Discussion}

The cancer has killed several individuals and the definite cure of cancer is not available until now. The modern chemotherapy drugs induce treatment relate resistance and tumours stop responding to these treatments. The various mechanisms are responsible for induction of drug resistance in tumours. ${ }^{24}$ The over expression of antioxidant enzyme is one of them. Therefore, present study was undertaken to study the effect of aqueous extract of $H$. nilagirica on the activities of GST, CAT and SOD and also lipid peroxidation in the Dalton's lymphoma ascites tumour cells transplanted into female Swiss albino mice.

The reactive oxygen species (ROS) including, superoxide, hydroxyl, nitric oxide free radicals and hydrogen peroxide are produced during oxidative phosphorylation in the organisms utilizing oxygen to produce chemical energy for their daily requirements. ${ }^{25-27}$ Despite the fact that ROS play important role in cell signalling, their rise is responsible for increased oxidative stress which is indicated in pathophysiology of numerous diseases including cancer. ${ }^{28-30}$ The glutathione contents have been reported to increase neoplastic transformation, drug resistance and cancer treatment failure. ${ }^{31-33}$ The glutathione is an important antioxidant molecule synthesized by the cells to neutralize or remove toxins. It is also essential in cell 
proliferation, cell differentiation and removal of damaged cells by apoptosis. ${ }^{34-37}$ High concentration of glutathione has been reported in the cancer cells. ${ }^{38}$ A similar effect has been reported in the present study, where DLA cells showed a higher amount of GSH. The DLA cells have been previously reported to exhibit higher GSH amount. ${ }^{39}$ The attrition of GSH is responsible for increase in oxidative stress and kill cells effectively. ${ }^{40-43}$ The treatment of tumourized mice with HNA led to a significant reduction in the GSH contents in DLA cells, which may be the reason for its tumour cell killing effect in our earlier studies. ${ }^{15,16}$ A similar effect has been reported earlier in DLA cells treated with Colocasia gigentea. ${ }^{39}$

Glutathione-s-transferase is an important antioxidant phaseII enzyme, which is involved in protecting cells from the reactive electrophilic attack by catalysing the detoxification of many exogenous and endogenous substances by the cells. ${ }^{44}$ The increased activity of GST is directly related to resistance to chemotherapy and radiotherapy. ${ }^{45-47}$ The increased GST activity has been reported in several rodents and human cancer cells. ${ }^{48}$ The DLA cells have shown higher GST activity and a similar observation has been made earlier in these cells. ${ }^{39}$ The depletion in GST activity in DLA cells treated with HNA may have contributed to its cytotoxic effect in our earlier study in vivo and in vitro. ${ }^{15,16} \mathrm{~A}$ similar effect has been reported in DLA cells exposed to ethanol extract of Colocasia gigentea earlier. ${ }^{39}$ GST activity has been reported to decline in cholangiocarcinoma cells treated with phenethyl isothiocyanate found in various cruciferous vegetables. ${ }^{49}$

Catalase also known as oxidoreductase is a tetrameric enzyme containing four polypeptide chains of more than 500 amino acids and it converts millions of hydrogen peroxide molecules into molecular oxygen and water every second..$^{50,51}$ Catalase is found in all organisms using oxygen for respiration..$^{52}$ The oxidative stress is higher in the tumour cells and as a result the catalase activity is higher in tumour cells. $^{52,53}$ The catalases are involved in the triggering of tumour resistance to therapy. ${ }^{54,55}$ Hence the depletion of catalase activity may be an important putative mechanism to treat tumours. The HNA administration has led to a significant decline in the catalase activity in the DLA tumourized mice, which may be directly correlated to its anticancer activity in vivo and in vitro in our earlier investigations. ${ }^{15,16}$ The ethanol extract of Colocasia gigentea exerted its anticancer effect in DLA tumorized mice earlier by lowering catalase activity. ${ }^{39}$

Superoxide dismutases are present in the aerobic organisms and they are involved in neutralizing the superoxide free radicals generated during oxidative phosphorylation in the mitochondria. It mainly converts superoxide free radicals into hydrogen peroxide and oxygen. ${ }^{56-58}$ The SODs are reported to be higher in the tumour cells and they increase the survival of tumour cells and also make tumours resistant to therapeutic intervention. ${ }^{57,59-61}$ The DLA tumourized mice administered with HNA showed a significantly alleviated estimation of SOD activity in tumour cells. A similar effect has been observed in DLA cells tumour bearing mice treated with Colocasia gigentea earlier. $^{39}$

Peroxidation of lipids is a common phenomenon in biological systems and LOO also serves as a signalling molecule. ${ }^{62,63}$ Despite the fact that LOO is involved in cell signalling it induces cytotoxic effect in the cells undergoing peroxidation of lipids. ${ }^{64} \mathrm{LOO}$ induces oxidative stress, which may trigger the non-apoptotic form of cell death. ${ }^{64,65}$ The treatment of tumourized mice with HNA raised the LOO in DLA cells significantly. This may have caused the cytotoxic effect of HNA in the earlier studies. ${ }^{15,16}$ Earlier Colocasia gigentea has been reported to exert cytotoxic effect on DLA cells due to increased LOO. ${ }^{39}$ Similarly, cytotoxicity on Ehrlich's ascites cells has been reported to be due to the increased LOO by Alstonia scholaris in an earlier study. ${ }^{66}$

The exact mechanism of decline in the antioxidant enzymes including GST, CAT and SOD and GSH is not known. The Nrf2 is activated due to increase in oxidative stress and this is the reason that $\mathrm{Nrf2}$ is overexpressed in tumour cells, which increases the amount of GSH, GST, CAT and SOD. ${ }^{67,68}$ The decrease in the GSH, GST, CAT and SOD in the HNA treated mice may be due to the suppression of the activation of Nrf2 by HNA in DLA cells.

\section{Conclusion}

The administration of $175 \mathrm{mg} / \mathrm{kg}$ of HNA in tumourized mice with DLA cells led to a decline in the GSH concentration and GST, catalase and SOD activities followed with a rise in the lipid peroxidation in the DLA cells. This would have been due to the reduction in Nrf2 signalling pathway in the DLA cells. The down modulation of Nrf2 elements followed by the rise in LOO and decline in the GSH contents and activities of GST, CAT and SOD by HNA may have been responsible for its ability to increase tumor free survivors in our earlier study.

\section{Acknowledgments}

The authors are thankful to the Department of Biotechnology, Government of India, New Delhi vide Grant No. BT/60/NE/ $\mathrm{TBP} / 2011$ for providing financial assistance to carry out this study to Prof. Ganesh Chandra Jagetia.

\section{Conflicts of interest}

The authors have no conflict of interest statement to declare.

\section{References}

1. Newman DJ, Cragg GM. Natural products as sources of new drugs from 1981 to 2014. J Nat Prod. 2016;79(3):629-661.

2. Nothias LF, Nothias Esposito M, da Silva R, et al. Bioactivity-based molecular networking for the discovery of drug leads in natural product bioassay-guided fractionation. J Nat Prod. 2018;81(4):758-767.

3. Shen B. A new golden age of natural products drug discovery. Cell. 2015;163(6):1297-1300.

4. Kinghorn AD, De Blanco EJ, Lucas DM, et al. Discovery of anticancer agents of diverse natural origin. Anticancer Res. 2016;36(11):5623-5637.

5. Pye CR, Bertin MJ, Lokey RS, et al. Retrospective analysis of natural products provides insights for future discovery trends. Proc Natl Acad Sci. 2017;114(22):5601-5606.

6. Zheng HC. The molecular mechanisms of chemoresistance in cancers Oncotarget. 2017;8(35):59950.

7. Jo Y, Choi N, Kim K, et al. Chemoresistance of cancer cells: requirements of tumor microenvironment-mimicking in vitro models in anti-cancer drug development. Theranostics. 2018;8(19):5259-5275.

8. Ong CK, Bodekar G, Grundy C, et al. WHO global atlas on traditional, complementary and alternative medicine (TCAM). WHO Centre for Health Development, Kobe, Japan, 2005:1-57.

9. Lettner S, Kessel KA, Combs SE. Complementary and alternative medicine in radiation oncology. Strahlenther Onkol. 2017;193(5):419 425 .

10. Johnson SB, Park HS, Gross CP, et al. Use of alternative medicine for cancer and its impact on survival. J Natl Cancer Inst. 2018;110(1):121124. 
11. Berretta M, Della Pepa C, Tralongo P, et al. Use of Complementary and Alternative Medicine (CAM) in cancer patients: An Italian multicenter survey. Oncotarget. 2017;8(15):24401.

12. Rocha V, Ladas EJ, Lin M, et al. Beliefs and determinants of use of traditional complementary/alternative medicine in pediatric patients who undergo treatment for cancer in South America. $J$ Global Oncol. 2017;3(6):701-710.

13. Kuo YH, Tsay SL, Chang CC, et al. Cancer impact, complementary/ alternative medicine beliefs, and quality of life in cancer patients. $J$ Alt Compl Med. 2018;24(3):276-281.

14. Khamyong S, Lykke AM, Seramethakun D, et al. Species composition and vegetation structure of an upper montane forest at the summit of Mt. Doi Inthanon, Thailand. Nord J Bot. 2004;23(1):83-97.

15. Zoremsiami J, Jagetia GC. Evaluation of the cytotoxic effects of Helicia nilagirica Bedd in vitro. Int J Sci Res. 2017;6(9):497-502.

16. Jagetia GC, Zoremsiami J. Anticancer activity of Helicia nilagirica Bedd in mice transplanted with Dalton's lymphoma. Int $J$ Complement Alt Med. 2018;11(2):112-123.

17. Lalawmpuii PC, Malsawmtluangi C, Vanlalruata R, et al. Evaluation of anti-inflammatory activity of Helicia nilagirica Bedd on cotton pelletinduced granuloma in rats. Int J Pharm Pharm Sci. 2016;8(7):455-456.

18. Bradford MM. A rapid and sensitive method for the quantitation of microgram quantities of protein utilizing the principle of protein-dye binding. Anal Biochem. 1976;72(1-2):248-254.

19. Moron MS, Depierre JW, Mannervik B. Levels of glutathione, glutathione reductase and glutathione S-transferase activities in rat lung and liver Biochim Biophy Acta. 1979;582(1):67-78.

20. Habig WH, Pabst MJ, JakobyWB. Glutathione S-transferases. The first enzymatic step in mercapturic acid formation. $J$ Biol Chem. 1974;249(22):7130-7139.

21. Aebi H. Catalase in vitro. Methods Enzymol. 1984;105:121-126.

22. Fried R. Enzymatic and non-enzymatic assay of superoxide dismutase Biochimie. 1975;57(5):657-660.

23. Ohkawa ON, Yagi K. Assay for lipid peroxides in animal tissues by thiobarbituric acid reaction. Anal Biochem. 1979;95(2):391-398.

24. Gottesman MM. Mechanisms of cancer drug resistance. Ann Rev Med. 2002;53(1):615-627.

25. Abdal Dayem A, Hossain M, Lee S, et al. The role of reactive oxygen species (ROS) in the biological activities of metallic nanoparticles. Int $J$ Mol Sci. 2017;18(1):120.

26. Sies H. Oxidative stress: a concept in redox biology and medicine. Redox Biol. 2015;4:180-183.

27. Sies H. On the history of oxidative stress: Concept and some aspects of current development. Curr Opin Toxicol. 2018;7:122-126.

28. Dickinson BC, Chang CJ. Chemistry and biology of reactive oxygen species in signaling or stress responses. Nat Chem Biol. 2011;7(8):504 511.

29. Weidinger A, Kozlov A. Biological activities of reactive oxygen and nitrogen species: oxidative stress versus signal transduction. Biomolecules. 2015;5(2):472-484.

30. Reczek CR, Chandel NS. The two faces of reactive oxygen species in cancer. Ann Rev Cancer Biol. 2017;1:79-98.

31. Traverso N, Ricciarelli R, Nitti M, et al. Role of glutathione in cancer progression and chemoresistance. Oxid Med Cell Longev. 2013;2013:972913.
32. Ramsay EE, Dilda PJ. Glutathione S-conjugates as prodrugs to target drug-resistant tumors. Front Pharmacol. 2014;5:181.

33. Bansal A, Simon MC. Glutathione metabolism in cancer progression and treatment resistance. J Cell Biol. 2018;217(7):2291-2298.

34. Meister A, Anderson ME. Glutathione. Ann Rev Biochem 1983;52(1):711-760.

35. Lushchak VI. Glutathione homeostasis and functions: potential targets for medical interventions. J Amino Acids. 2012;2012:736837.

36. Liu Y, Hyde AS, Simpson MA, et al. Emerging regulatory paradigms in glutathione metabolism. Adv Cancer Res. 2014;122:69-101.

37. Forman HJ. Glutathione-From antioxidant to post-translational modifier Arch Biochem Biophys. 2016;595:64-67.

38. Godwin AK, Meister A, O’Dwyer PJ, et al. High resistance to cisplatin in human ovarian cancer cell lines is associated with marked increase of glutathione synthesis. Proc Natl Acad Sci. 1992;89(7):3070-3074.

39. Devi N B, Jagetia GC. Antitumor activity of different extracts of Colocasia gigantea in Dalton's lymphoma transplanted Swiss Albino mice. Int Res J Pharmaceut Biosci. 2017;4(4):52-82.

40. Ortega AL, Mena S, Estrela JM. Glutathione in cancer cell death Cancers. 2011;3(1):1285-1310.

41. Gamcsik MP, Kasibhatla MS, Teeter SD, et al. Glutathione levels in human tumors. Biomarkers. 2012;17(8):671-691.

42. Rocha CR, Garcia CC, Vieira DB, et al. Glutathione depletion sensitizes cisplatin-and temozolomide-resistant glioma cells in vitro and in vivo. Cell Death Dis. 2014;5(10):e1505.

43. Miran T, Vogg AT, Drude N, et al. Modulation of glutathione promotes apoptosis in triple-negative breast cancer cells. The FASEB J. 2018;32(5):2803-2813.

44. Tew KD, Townsend DM. Glutathione-s-transferases as determinants of cell survival and death. Antioxid Redox Signal. 2012;17(12):1728-1737.

45. Townsend DM, Tew KD. The role of glutathione-S-transferase in anticancer drug resistance. Oncogene. 2003;22(47):7369-7375.

46. Tew KD. Glutathione-associated enzymes in anticancer drug resistance. Cancer Res. 2016;76(1):7-9.

47. Allocati N, Masulli M, Di Ilio C, et al. Glutathione transferases: substrates, inhibitors and pro-drugs in cancer and neurodegenerative diseases. Oncogenesis. 2018;7(1):8.

48. Beaumont PO, Moore MJ, Ahmad K, et al. Role of glutathione S-transferases in the resistance of human colon cancer cell lines to doxorubicin. Cancer Res. 1998;58(5):947-955.

49. Tusskorn O, Khunluck T, Prawan A, et al. Suppression of glutathione S-transferases potentiates the cytotoxic effect of phenethyl isothiocyanate in cholangiocarcinoma cells. Naunyn-Schmiedeberg's Arch Pharmacol. 2018;391(6):657-667.

50. Loew O. A new enzyme of general occurrence in organisms. Science. 1900;11(279):701-702

51. Chelikani P, Fita I, Loewen PC. Diversity of structures and properties among catalases. Cell Mol Life Sci CMLS. 2004;61(2):192-208.

52. Kirkman HN, Gaetani GF. Mammalian catalase: a venerable enzyme with new mysteries. Trends Biochem Sci. 2007;32(1):44-50.

53. Ho JC, Zheng S, Comhair SA, et al. Differential expression of manganese superoxide dismutase and catalase in lung cancer. Cancer Res. 2001;61(23):8578-8585. 
54. Glorieux C, Sandoval JM, Dejeans N, et al. Evaluation of potential mechanisms controlling the catalase expression in breast cancer cells. Oxid Med Cell Long. 2018;2018:5351967.

55. Bauer G. Tumor cell-protective catalase as a novel target for rationa therapeutic approaches based on specific intercellular ROS signaling. Anticancer Res. 2012;32(7):2599-2624.

56. Fukai T, Ushio-Fukai M. Superoxide dismutases: role in redox signaling, vascular function, and diseases. Antioxid Redox Signal. 2011;15(6):15831606.

57. Che M, Wang R, Li X, et al. Expanding roles of superoxide dismutases in cell regulation and cancer. Drug Dis Today. 2016;21(1):143-149.

58. Azadmanesh J, Borgstahl G. A review of the catalytic mechanism of human manganese superoxide dismutase. Antioxidants. 2018;7(2):25.

59. Somwar R, Erdjument-Bromage H, Larsson E, et al. Superoxide dismutase 1 (SOD1) is a target for a small molecule identified in a screen for inhibitors of the growth of lung adenocarcinoma cell lines. Proc Natl Acad Sci. 2011;108(39):16375-16380.

60. Kodydková J, Vávrová L, Kocík M, et al. Human catalase, its polymorphisms, regulation and changes of its activity in different diseases. Folia Biol. 2014;60(4):153-167.

61. Fu A, Ma S, Wei N, et al. High expression of MnSOD promotes survival of circulating breast cancer cells and increases their resistance to doxorubicin. Oncotarget. 2016;7(31):50239.
62. Higdon A, Diers AR, Oh JY, et al. Cell signalling by reactive lipid species: new concepts and molecular mechanisms. Biochem J. 2012;442(3):453464.

63. Garrec J, Monari A, Assfeld X, et al. Lipid peroxidation in membranes: the peroxyl radical does not "float". J Phys Chem Lett. 2014;5(10):16531658

64. Gaschler MM, Stockwell BR. Lipid peroxidation in cell death. Biochem Biophys Res Commun. 2017;482(3):419-425.

65. Magtanong L, Ko PJ, Dixon SJ. Emerging roles for lipids in nonapoptotic cell death. Cell Death Different. 2016;23(7):1099-1109.

66. Jagetia GC, Baliga MS. Preclinical evaluation of the anticancer activity of hydroalcoholic stem bark extract of Alstonia scholaris in Ehrlich ascites carcinoma transplanted in the Swiss albino mice. J Alt Med Res. 2016;2(2):115

67. Nguyen T, Nioi P, Pickett CB. The Nrf2-antioxidant response element signaling pathway and its activation by oxidative stress. $J$ Biol Chem. 2009;284(20):13291-13295.

68. Menegon S, Columbano A, Giordano S. The dual roles of NRF2 in cancer. Trends Mol Med. 2016;22(7):578-593. 